\section{A TIDAL PROBLEM}

$\mathrm{T}^{\mathrm{H}}$

$\mathrm{HE}$ so-called seiches, or alternate flux and reflux of water in the Lake of Geneva and other bodies of fresh water, have, as our readers know, formed the subject of an interesting study during the past decade by Dr. F. A. Forel, of Morges, near Geneva. Small local tides are constantly noticeable there, the difference between ebb and flow varying from a few centimetres to 2 metres. Their cause is to be traced to the wind, variations in atmospheric pressure at the extremities of the lake, \&c. Dr. Forel, as the result of his investigations has established a formula by means of which the duration of a local ebb and flow can be determined-not only for the Lake of Geneva, but for any lake-when its average depth and its length are known. The following is the formula $T=2 \frac{2 \mathrm{~L}}{\sqrt{g h}}$, in

which $L$ denotes the length of the lake, $h$ its average depth, and $g$ the acceleration of gravity. This formula gives for the Lake of Geneva, which has a length of
73 kilometres, a duration of tide of 13 minutes; a figure coinciding with the fact.

The law thus established by $M$. Forel has recently received an interesting application in solving a problem which has puzzled travellers and philosophers for over 2,000 years, viz., the explanation of the currents in the narrow straits of Euripus, where the famous five-arched bridge of Egripo joins the Island of Eubœa to the mainland of Greece. The currents sweeping below the bridge are so violent that mills are kept in operation by them, but they are noted for the changes in direction which occur from four to fourteen times daily. Tradition relates that Aristotle, in despair at his inability to explain this phenomenon, threw himself from the bridge into the water.

A comparison of the large number of observations made upon this strange tidal movement shows that there are two distinct periods: that in which there are but four changes of direction or two tides in a lunar day of 24 hours and 50 minutes, and that in which these tides number from eleven to fourteen daily. This latter phenomenon is observable invariably at the quadratures of the

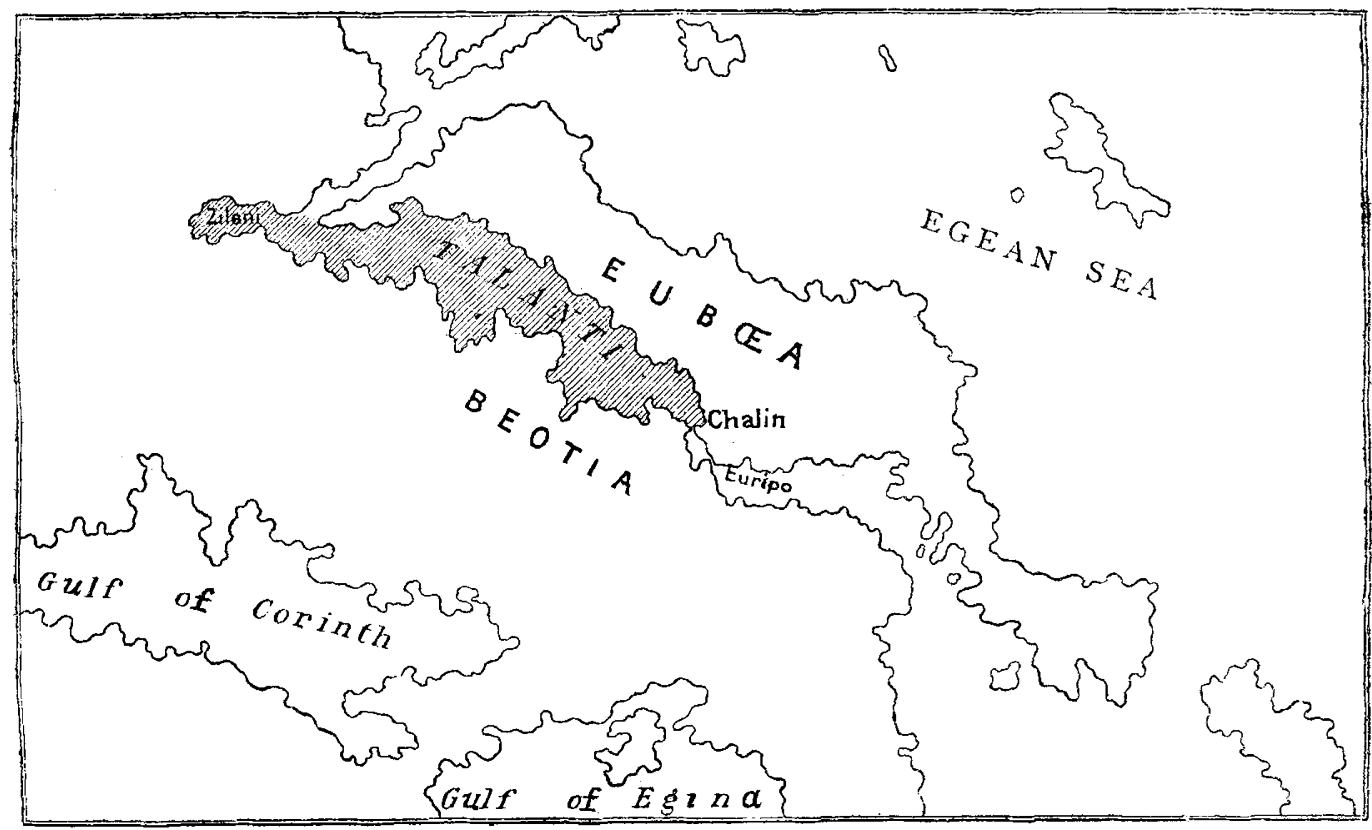

moon. M. Forel, in his explanation, shows that the regular ebb and flow twice a day in the former period is due to the tidal movement of the Egean Sea, which is then at its maximum. The increase in the number of tides daily becomes manifest, however, when the tidal force of the $Æ$ gean is at its minimum, viz., at the quadratures, and must be owing to some other force more powerful than the minimum but less powerful than the maximum force of the Egean tide. This force is found in the local tides or seiches of the Gulf of Talanti to the north of the straits, which is so shut in by land that it can practically be regarded as subject to the same laws as the lakes of Switzerland and other countries. This basin is I 5 kilometres long, and is from 100 to 200 metres in depth. Applying these figures to M. Forel's formula, the ebb and flow in the Gulf of Talanti would be for 100 metres, 122 minutes; for I50 metres, I00 minutes; for 200 metres, 86 minutes. The eleven to fourteen currents observable daily at Euripus during the quadratures last from 103 to $13 \mathrm{I}$ minutes. This shows so striking a conformity with the theory advanced by the Swiss savant, that we can but consider this problem, which so vexed the ancients, as fairly solved.
Dr. Forel asks intelligent visitors to the locality to verify his interpretation by attending especially to the following points:- $\mathbf{r}$. Ascertain the exact duration of the flux and reflux of the Euripus, and determine its normal rhythm. 2. Ascertain if, as in the seiches of the Lake of Geneva, the amplitude of the flux and reflux of the irregular current is stronger in bad weather than when there are no atmospherical perturbations. 3. Ascertain if the connections between the direction of the current and the flow of the rising sea are, as he supposes, inverse, according as the current is regular or irregular.

\section{NOTES}

THE great osteological collection which Dr. Barnard Davis, F.R.S., has accumulated during a long life devoted to anthropological pursuits is well known, both in England and abroad, as the richest and most valuable ever formed by a private individual, exceeding, as it does, in variety and rarity of the specimens all the public collections of this country and most of those on the Continent. It contains about eighteen luundred specimens of skulls and skeletons of various races of men, the value of 